\title{
Microphysics and heterogeneous chemistry in aircraft plumes - high sensitivity on local meteorology and atmospheric composition
}

\author{
S. K. Meilinger ${ }^{1}$, B. Kärcher ${ }^{2}$, and Th. Peter ${ }^{3}$ \\ ${ }^{1}$ Max Planck Institute for Chemistry, Mainz, Germany \\ ${ }^{2}$ DLR Oberpfaffenhofen, Institute for Atmospheric Physics, Wessling, Germany \\ ${ }^{3}$ Institute for Atmospheric and Climate Sciences, ETH Zürich, Switzerland
}

Received: 29 February 2004 - Published in Atmos. Chem. Phys. Discuss.: 11 August 2004

Revised: 8 December 2004 - Accepted: 20 December 2004 - Published: 21 February 2005

\begin{abstract}
An aircraft plume model has been developed on the basis of two coupled trajectory box models. Two boxes, one for plume and one for background conditions, are coupled by means of a mixing parameterization based on turbulence theory. The model considers comprehensive gas phase chemistry for the tropopause region including acetone, ethane and their oxidation products. Heterogeneous halogen, $\mathrm{N}_{2} \mathrm{O}_{5}$ and $\mathrm{HO}_{\mathrm{x}}$ chemistry on various types of background and aircraft-induced aerosols (liquid and ice) is considered, using state-of-the-art solubility dependent uptake coefficients for liquid phase reactions. The microphysical scheme allows for coagulation, gas-diffusive particle growth and evaporation, so that the particle development from $1 \mathrm{~s}$ after emission to several days can be simulated. Model results are shown, studying emissions into the upper troposphere as well as into the lowermost stratosphere for contrail and noncontrail conditions. We show the microphysical and chemical evolution of spreading plumes and use the concept of mean plume encounter time, $t_{l}$, to define effective emission and perturbation indices ( $E E I \mathrm{~s}$ and $E P I \mathrm{~s})$ for the North Atlantic Flight Corridor (NAFC) showing $E E I\left(\mathrm{NO}_{\mathrm{y}}\right)$ and $E P I\left(\mathrm{O}_{3}\right)$ for various background conditions, such as relative humidity, local time of emission, and seasonal variations. Our results show a high sensitivity of $E E I$ and $E P I$ s on the exact conditions under which emissions take place. The difference of $E E I$ s with and without considering plume processes indicates that these processes cannot be neglected.
\end{abstract}

\section{Introduction}

In view of the growth of commercial air traffic there has been a large scientific interest in the impact of aircraft emissions over the last three decades. Chemistry Transport Mod-

Correspondence to: S. K. Meilinger

(Stefanie.Meilinger@erm.com) els (CTMs) are required to evaluate global atmospheric effects and possible climatic consequences of aviation (e.g. IPCC, 1999). However, since global 3-D models have relatively coarse grids, these models cannot take detailed account of the processes in aircraft exhaust plumes. Consequently, effects of high pollutant mixing ratios which initially exist in young plumes are missing in such model simulations. Recently, there have been a couple of studies accounting for in-plume conversion of emitted species such as $\mathrm{NO}_{\mathrm{x}}$ (e.g. Meijer et al., 1997; Petry et al., 1998; Kraabøl et al., 2000a,b; Kraabøl and Stordal, 2000; Karol et al., 2000). However, in contrast to the model introduced in this work, these models do not provide a detailed treatment of plume particle microphysics and heterogeneous chemistry, even though airplanes produce not only gaseous emission, but liquid and solid particles as well. Aircraft particles form shortly after the engine exit (e.g. Fahey et al., 1995; Schumann, 1996; Kärcher, 1999). Microphysical models of particle formation suggest that aerosol surface area densities of $10^{3}-10^{5} \mu \mathrm{m}^{2} \mathrm{~cm}^{-3}$ or more are present in young aircraft plumes (Kärcher et al., 1996; Brown et al., 1996). Such high initial surface area densities are supported by in-situ measurements (e.g. Kärcher et al., 1998b; Schröder et al., 1998). The specific ice surface areas in young contrails are of similar magnitude (Schröder et al., 2000). Therefore heterogeneous processes can become important in young aircraft plumes if they are fast enough to compete with particle number decrease due to mixing and scavenging. Using calculated surface densities Kärcher (1997) derived boundaries for uptake coefficients $\gamma$ for efficient heterogeneous processing to proceed within a day: $\gamma \geq 0.003-0.007$ for reactions on aircraft-induced liquid aerosols and $\gamma \geq 0.1$ for reactions on contrail ice particles. However, the heterogeneous reaction efficiency does not only depend on the temporal evolution of aviation-induced particle surface area, but also on the abundance of heterogeneously reacting species. In the young plume, concentrations of aircraft emitted species, 


\section{Photochemical Trajectory Plume Box Model}

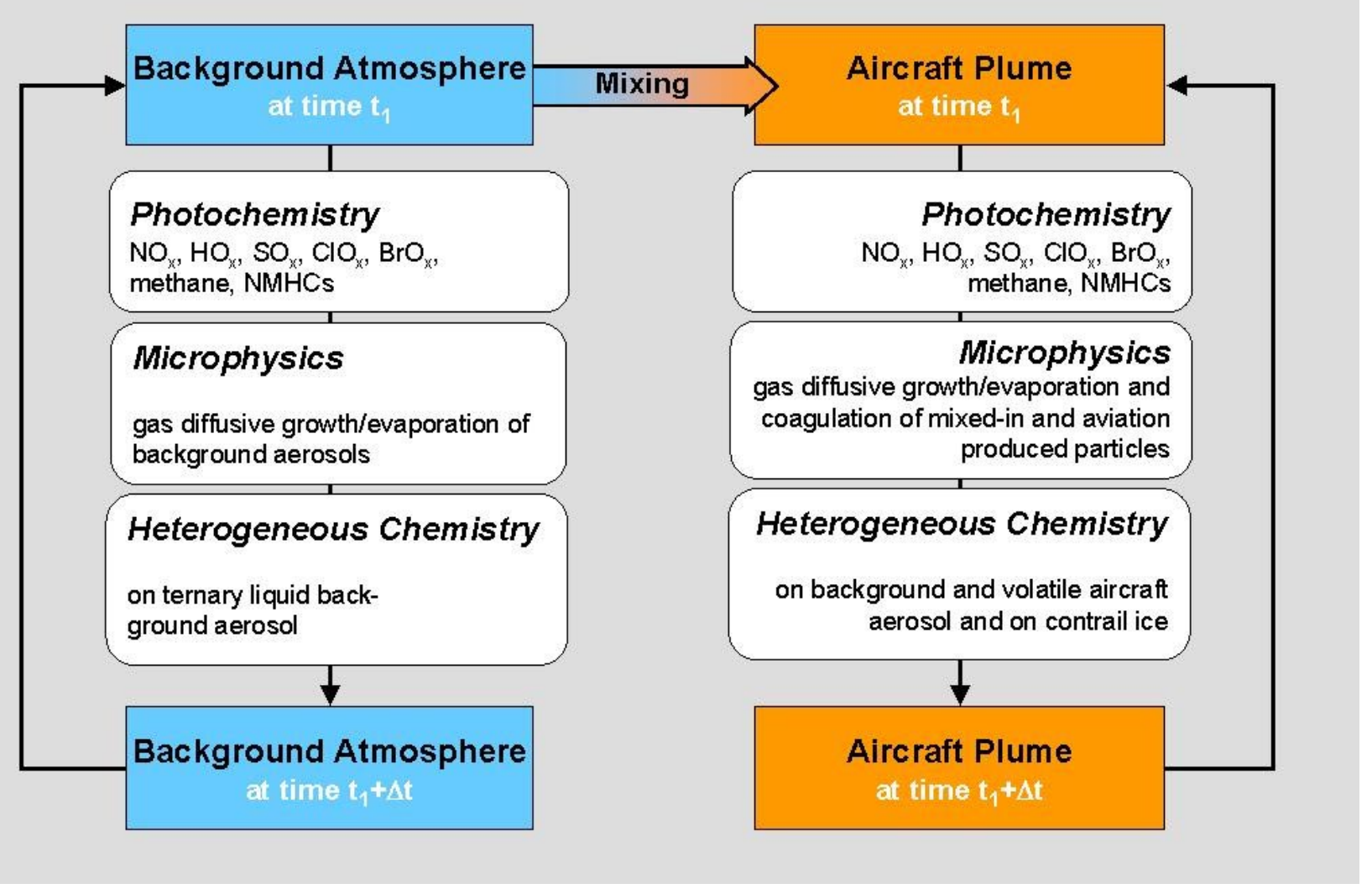

Fig. 1. Schematic representation of the Mainz Aircraft Plume Model.

such as $\mathrm{NO}_{\mathrm{x}}$ and $\mathrm{H}_{2} \mathrm{O}$, are far above background concentrations disturbing gas-phase chemistry and affecting heterogeneous reactions via repartitioning of heterogeneously reacting species. In addition, heterogeneous reaction rates and uptake coefficients can be solubility dependent and thus limited by the Kelvin effect, especially for small particles with diameters below about $10 \mathrm{~nm}$ as those produced in jet exhaust plumes (Meilinger et al., 2002). Therefore, in order to correctly estimate the effect of heterogeneous chemistry in dispersing aircraft wakes, we have to consider both, chemical and microphysical interactions together with mixing of the plume with ambient air.

Here we present the Mainz Aircraft Plume Model, which contains a large set of microphysical and chemical interactions, including coagulation, gas-diffusive particle growth and heterogeneous chemistry on liquid and ice particles, using solubility dependent uptake coefficients for liquid phase reactions including the Kelvin effect. A detailed model description is given in Sect. 2. Section 3 contains results of this plume model for conditions with and without contrail formation distinguishing emissions into the lowermost stratosphere and into the upper troposphere. Section 4 introduces the concept of effective emission indices (EEI) and effective perturbation indices $(E P I)$ using the concept of average plume encounter time, $t_{l}$, of Kärcher and Meilinger (1998). Our results show that effective emissions and perturbations clearly depend on the exact composition of the background atmosphere. While heterogeneous chemistry on persistent contrail ice particles determines the $\mathrm{NO}_{\mathrm{x}}$ conversion and the ozone chemistry in the plume, heterogeneous reactions are of minor importance in the non-contrail case.

\section{Model description}

The Mainz Aircraft Plume Model is a photochemical trajectory box model which consists of two separate boxes: a box describing heterogeneous photochemistry of the background atmosphere and a box representing chemical and microphysical plume processes (Fig. 1).

The model contains comprehensive gas phase chemistry for the tropopause region including acetone, ethane and their oxidation products as precursors for PAN, which acts as $\mathrm{NO}_{\mathrm{x}}$ sink; comprehensive heterogeneous chemistry for deactivation of $\mathrm{NO}_{\mathrm{x}}$ and $\mathrm{HO}_{\mathrm{x}}$ and activation of chlorine and bromine 
Table 1. Aircraft Emission Indices used in the model.

\begin{tabular}{lrl}
\hline species & emission index & unit \\
\hline $\mathrm{CO}$ & 5 & $(\mathrm{~g} \mathrm{CO} / \mathrm{kg}-f u e l)$ \\
$\mathrm{H}_{2} \mathrm{O}$ & 1240 & $(\mathrm{~g} \mathrm{H} 2 \mathrm{O} / \mathrm{kg}$-fuel $)$ \\
$\mathrm{N}$ & 6.5 & $(\mathrm{~g} \mathrm{~N} / \mathrm{kg}$-fuel $)$ \\
$\mathrm{S}$ & 0.40 & $(\mathrm{~g} \mathrm{~S} / \mathrm{kg}-f u e l)$ \\
Ion-particles & $2.6 \times 10^{17}$ & $($ ptcls/kg-fuel) \\
Soot & 0.04 & $(\mathrm{~g} \mathrm{soot} / \mathrm{kg}$-fuel $)$ \\
\hline
\end{tabular}

Table 2. Conversion efficiencies $(\eta)$ describing the conversion of primary into secondary emission products (e.g. Kärcher, 1999).

\begin{tabular}{llll}
\hline & & & \\
\hline $\mathrm{OH}$ & $\rightarrow$ & $\mathrm{H}_{2} \mathrm{O}_{2}$ & $2 \%$ \\
$\mathrm{NO}_{2}$ & $\rightarrow$ & $\mathrm{HNO}_{3}$ & $5 \%$ \\
$\mathrm{NO}$ & $\rightarrow$ & $\mathrm{HNO}_{2}$ & $2 \%$ \\
$\mathrm{SO}_{2}$ & $\rightarrow$ & $\mathrm{H}_{2} \mathrm{SO}_{4}$ & $0.5 \%$ \\
$\mathrm{SO}_{3}$ & $\rightarrow$ & $\mathrm{H}_{2} \mathrm{SO}_{4}$ & $5 \%$ \\
\hline
\end{tabular}

on various types of background or aircraft-induced aerosol modes (not size-resolved). Heterogeneous photochemistry is integrated for each box separately, and at each time step the calculated background concentrations are used to determine the mixing of ambient air into the plume. Initial plume composition is mainly determined by aircraft emissions of $\mathrm{NO}_{\mathrm{x}}$, water, $\mathrm{CO}$ and particle precursors, besides entrainment from the atmosphere encompassing the plume.

While both parts of the model have identical gas phase photochemistry, the plume contains extended microphysics, considering the different aircraft produced particle modes besides background aerosol particles entrained from the background atmosphere (Fig. 2). The model calculates coagulation between the various modes, considers gas diffusive condensation/evaporation of liquid and ice particle modes, and accounts for additional heterogeneous chemistry on aviationproduced liquid and ice particles.

The temporal evolution of any trace species (gas or particle) in the exhaust can be described by the following equation

$\frac{d \chi}{d t}=\left(\delta_{t} \chi\right)_{m i x}+\left(\delta_{t} \chi\right)_{c h m}+\left(\delta_{t} \chi\right)_{m i c}$,

where $\chi$ is the gas phase mixing ratio of the trace species in the plume. The first term describes the mixing with ambient air. The composition of the unperturbed ambient air is calculated with the background model. The second and third terms describe the temporal changes of the species' mixing ratio due to chemical and microphysical processes, respectively. Initialization, mixing, chemistry and microphysics in the plume will be discussed below, distin-

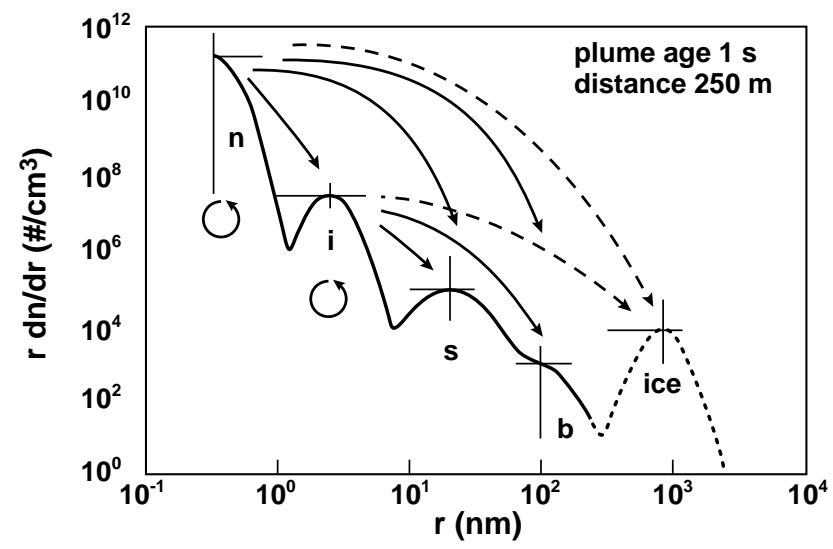

Fig. 2. Particle modes in aircraft plumes and coagulation scheme. The initial aerosol size distribution (adopted from Kärcher, 1999) in the plume considers neutral $(n)$ and ion $(i)$ particles produced in the nascent plume, emitted soot $(s)$, entrained background aerosols (b), and contrail ice. The arrows indicate scavenging paths between particle modes. Self-coagulation (closed circles) is important for $n$ and $i$, but negligible for the $s, b$ and ice modes. The ice mode is plotted as a dotted line to indicate that this mode does not always occur and that the other aerosol-modes are only modified by the dashed coagulation paths if ice is present. The thin lines indicate the range of mean sizes and total number densities of each particle mode.

guishing between coagulation and gas diffusive condensation/evaporation: $\left(\delta_{t} \chi\right)_{m i c}=\left(\delta_{t} \chi\right)_{\text {coag }}+\left(\delta_{t} \chi\right)_{\text {cond }}$.

\subsection{Initialization and mixing}

The plume is initialized at time $t_{p, 0}=1 \mathrm{~s}$ after the exhaust gases leave the nozzle exit plane, assuming an initial dilution factor of exhaust gases of $1 \%$ after $1 \mathrm{~s}$ (Kärcher et al., 1996). The initial plume concentrations are partly determined by the aircraft emitted gases and their oxidation products and partly by the entrained background species at $t_{p, 0}$. Emission indices were taken from Kärcher (1999) and are listed in Table 1.

The model takes into account emissions of $\mathrm{CO}, \mathrm{H}_{2} \mathrm{O}, \mathrm{NO}_{\mathrm{x}}$, sulfur, soot particles and volatile "ion particles" formed from chemi-ions, which are produced by chemical reactions in the combustors and are emitted by the aircraft engines. Sulfur is mainly emitted as $\mathrm{SO}_{2}\left(\mathrm{SO}_{2} /\left(\mathrm{SO}_{2}+\mathrm{SO}_{3}\right)=90 \%\right)$, while nitrogen oxides are mainly emitted as $\mathrm{NO}(90 \%)$ and to a smaller fraction in the form of $\mathrm{NO}_{2}(10 \%)$. Initial $\mathrm{HO}_{\mathrm{x}}$ concentrations $(\mathrm{OH}=10 \mathrm{ppmv})$ are similar to those of Kärcher et al. (1996). The conversion efficiencies for the emission of secondary products are listed in Table 2 .

Plume mixing with ambient air is calculated according to

$\left(\delta_{t} \chi\right)_{\operatorname{mix}}=-\omega\left(\chi-\chi_{b}\right)$,

where $\omega=\alpha / t$ is the average entrainment rate, describing plume mixing with ambient background air (subscript $b$ ). A typical value of $\alpha=0.8$ (Schumann et al., 1998) is used as 
Table 3. Heterogeneous reactions and their reaction probabilities $\gamma$ on liquid ternary aerosol and ice surfaces implemented in the box model. Solubility dependent $\gamma \mathrm{s}$, indicated with $(\star)$, are calculated according to Hanson et al. (1994) and Peter (1997).

\begin{tabular}{|c|c|c|c|c|c|}
\hline \multirow{2}{*}{$\begin{array}{l}\text { No. } \\
\text { H1 }\end{array}$} & \multicolumn{3}{|c|}{ Heterogeneous Reaction } & \multirow{2}{*}{$\frac{\gamma_{l i q}}{0.1}$} & \multirow{2}{*}{$\frac{\gamma_{\text {ice }}}{0.01}$} \\
\hline & $\mathrm{N}_{2} \mathrm{O}_{5}+\mathrm{H}_{2} \mathrm{O}$ & $\rightarrow$ & $2 \mathrm{HNO}_{3}$ & & \\
\hline $\mathrm{H} 2$ & $\mathrm{~N}_{2} \mathrm{O}_{5}+\mathrm{HCl}$ & $\rightarrow$ & $\mathrm{ClNO}_{2}+\mathrm{HNO}_{3}$ & - & 0.03 \\
\hline H3 & $\mathrm{HO}_{2}$ & $\rightarrow$ & $0.5 \mathrm{H}_{2} \mathrm{O}_{2}+\mathrm{O}_{2}$ & 0.2 & 0.025 \\
\hline $\mathrm{H} 4$ & $\mathrm{OH}$ & $\rightarrow$ & $0.5 \mathrm{H}_{2} \mathrm{O}_{2}$ & 0.1 & 0.01 \\
\hline H5 & $\mathrm{ClONO}_{2}+\mathrm{H}_{2} \mathrm{O}$ & $\rightarrow$ & $\mathrm{HOCl}+\mathrm{HNO}_{3}$ & $\star$ & 0.3 \\
\hline H6 & $\mathrm{ClONO}_{2}+\mathrm{HCl}$ & $\rightarrow$ & $\mathrm{Cl}_{2}+\mathrm{HNO}_{3}$ & $\star$ & 0.3 \\
\hline $\mathrm{H} 7$ & $\mathrm{ClONO}_{2}+\mathrm{HBr}$ & $\rightarrow$ & $\mathrm{BrCl}+\mathrm{HNO}_{3}$ & - & 0.3 \\
\hline H8 & $\mathrm{HOCl}+\mathrm{HCl}$ & $\rightarrow$ & $\mathrm{Cl}_{2}+\mathrm{H}_{2} \mathrm{O}$ & $\star$ & 0.3 \\
\hline H9 & $\mathrm{HOCl}+\mathrm{HBr}$ & $\rightarrow$ & $\mathrm{BrCl}+\mathrm{H}_{2} \mathrm{O}$ & $\star$ & 0.3 \\
\hline H10 & $\mathrm{BrONO}_{2}+\mathrm{H}_{2} \mathrm{O}$ & $\rightarrow$ & $\mathrm{HOBr}+\mathrm{HNO}_{3}$ & $\star$ & 0.3 \\
\hline H11 & $\mathrm{BrONO}_{2}+\mathrm{HCl}$ & $\rightarrow$ & $\mathrm{BrCl}+\mathrm{HNO}_{3}$ & - & 0.3 \\
\hline H12 & $\mathrm{HOBr}+\mathrm{HCl}$ & $\rightarrow$ & $\mathrm{BrCl}+\mathrm{H}_{2} \mathrm{O}$ & $\star$ & 0.3 \\
\hline H13 & $\mathrm{HOBr}+\mathrm{HBr}$ & $\rightarrow$ & $\mathrm{Br}_{2}+\mathrm{H}_{2} \mathrm{O}$ & $\star$ & 0.1 \\
\hline
\end{tabular}

default. Initial temperatures are slightly above background values (assuming an average temperature enhancement of $\Delta T=7 \mathrm{~K}$ at $1 \mathrm{~s}$ plume age). Cooling by mixing with ambient air is calculated using Eq. (2) with $\chi=T$.

\subsection{Chemistry}

The model integrates a set of differential equations, describing homogeneous and heterogeneous chemical reactions, delivering the time-development of all chemical species along a given trajectory. It uses FACSIMILE (Curtis and Sweetenham, 1987), a commercial software package, that uses an implicit integration scheme for stiff differential equations (Gear, 1971) with a self-adjusting time step.

\subsubsection{Homogeneous photochemistry}

The photochemistry is based on an updated extension (Meilinger et al., 2001) of the Mainz Photochemical Box Model (see Grooß, 1996, for details). In the Mainz Aircraft Plume Model, we added reactions that become relevant under highly polluted conditions, e.g. elevated $\mathrm{NO}_{\mathrm{x}}$ and $\mathrm{SO}_{\mathrm{x}}$ concentrations as they are present in young aircraft plumes. The actual model version treats 57 chemical species, including ozone and oxygen atoms, odd hydrogen radicals, nitrogen and sulfur species, inorganic chlorine and bromine compounds as well as the organic products involved in the methane, ethane and acetone oxidation chains. There are 123 gas phase (109 bimolecular and 14 termolecular) and 31 photolysis reactions (see Meilinger, 2000, for details). Kinetic reaction rates are taken from Atkinson et al. (1999) and Sander et al. (2003). Photolysis rates were calculated with an update (Becker et al., 2000) of the scheme by Lary and
Pyle (1991), using the ozone profile of the U.S. standard atmosphere at $50^{\circ} \mathrm{N}$.

\subsubsection{Heterogeneous chemistry}

In addition, the model contains 13 heterogeneous reactions on liquid and ice particles (see Table 3). For the model, we assumed uptake coefficients $\gamma$ evaluated for polar stratospheric clouds (Sander et al., 2003) to be applicable to tropopause conditions, except for the heterogeneous reaction of $\mathrm{HO}_{2}$, for which parameterizations by Jacob (2000) and Jaeglé et al. (2000) have been employed. We used solubility dependent uptake coefficients for heterogeneous reactions in supercooled liquid aerosols according to Hanson et al. (1994) and Peter (1997), except for pure surface reactions. Liquid aerosol is assumed to be composed of $\mathrm{H}_{2} \mathrm{O} / \mathrm{H}_{2} \mathrm{SO}_{4}$ solutions, which take up $\mathrm{HNO}_{3}, \mathrm{HOCl}, \mathrm{HCl}, \mathrm{HOBr}$ and $\mathrm{HBr}$ at sufficiently low temperatures (Carslaw et al., 1997). Note that we did not consider any heterogeneous reactions on soot in the present version of the model.

\subsection{Microphysics}

This section comprises a description of the various particle types and the processes they are undergoing.

\subsubsection{Particle Representation}

In order to consider mixed aerosol ensembles in the plume, it is necessary to adequately distinguish the various interacting particle modes in the aircraft exhaust plume. Each particle mode is represented by a log-normal distribution assuming constant distribution widths and variable mode radii and particles number densities, which change due to coagulation, gas diffusive condensation/evaporation and mixing processes. Figure 2 depicts the initial size distribution, estimated on the basis of observations and simulations (Kärcher, 1999).

Sulfur emissions are mainly responsible for the formation of new volatile particles in young aircraft plumes. In the model we consider two modes of volatile aircraft particles: a mode composed of electrically neutral molecular clusters (subscript $n$ ), with an initial mode radius of $\bar{r}_{n}=0.325 \mathrm{~nm}$, and an ion mode (subscript $i$ ), containing $\sim 10^{17}$ particles per kg of fuel that form on the emitted chemi-ions (Kärcher et al., 2000). Due to charge effects, the ion mode grows initially faster than the neutral mode $\left(\bar{r}_{i} \simeq 2.5-5 \mathrm{~nm}\right)$. Observed emission levels of exhaust soot (subscript $s$ ) at cruise range between $10^{14}$ to $10^{15}$ particles per $\mathrm{kg}$ of fuel (Petzold et al., 2003), which is consistent with the emission index of $0.04 \mathrm{~g} \mathrm{soot} / \mathrm{kg}$ fuel used in the model $\left(\bar{r}_{s}=5-15 \mathrm{~nm}\right)$.

Contrail formation is allowed if the diluting and cooling plume becomes supersaturated with respect to liquid water, a criterion which according to Applemann (1957) is a good approximation for the nucleation of ice under the conditions of a rapid supercooling plume. 
In the diluting plume, changes of $\mathrm{H}_{2} \mathrm{O}$ partial pressure and plume temperature (both following Eq. 2) combine such that (Schumann, 1996)

$S_{\mathrm{H}_{2} \mathrm{O}, \mathrm{p}}=\frac{c_{p} E I\left(\mathrm{H}_{2} \mathrm{O}\right)}{Q(1-\epsilon)}$,

where $c_{p}$ is the specific heat capacity of dry air, $E I\left(\mathrm{H}_{2} \mathrm{O}\right)$ is the emission index of water and $Q(1-\epsilon)$ is the fraction of the specific combustion heat, that is not used to propel the aircraft (in the plume model a combustion heat of $Q=41.85 \mathrm{~J} /(\mathrm{kg}$ fuel $)$ and a propulsion efficiency of $\epsilon=30 \%$ are assumed).

In a young plume there exist $\sim 10^{8}-10^{10} / \mathrm{cm}^{3}$ aerosol particles, on which typically $\geq 10^{4} / \mathrm{cm}^{3}$ ice particles may nucleate in a contrail. This compares to $10^{2}-10^{4} / \mathrm{cm}^{3}$ background aerosol particles at flight level, on which $10^{-4}-10^{2} / \mathrm{cm}^{3}$ ice particles nucleate in natural cirrus clouds, strongly depending on nucleation conditions This reveals that ice particles in contrails mainly nucleate on exhaust aerosols. The latter pass a liquid growth stage prior to freezing where they are activated into nearly pure liquid water droplets. Coated soot particles must likely be involved in the ice formation process (Schröder et al., 2000). Therefore, in the plume model, heterogeneous freezing of coated soot particles is assumed, if $\mathrm{S}_{\mathrm{H}_{2} \mathrm{O}, \mathrm{p}}$ exceeds gas phase supersaturation with respect to liquid water assuming formation of $10^{4}$ ice particles per $\mathrm{cm}^{3}$. In addition to the aviation-produced particles $(n, i, s, i c e)$, entrained liquid background aerosol particles are as well part of the considered mixed aerosol ensembles in the aircraft plume.

\subsubsection{Coagulation}

Brownian coagulation and scavenging control the microphysical evolution of particles in dispersing plumes, affecting the specific number density $n_{x}$ and the mode radius $\bar{r}_{x}$ of a particle mode $x(x=n, i, s, b, i c e)$. In order to calculate coagulation efficiencies for the various processes, a simplified coagulation scheme considering the most important coagulation paths (arrows in Fig. 2) was developed (constrained by comparison with results obtained from a full coagulation model; Kärcher et al., 1998a,b). Particles are represented by log-normal modes with time-dependent $n_{x}$ and $\bar{r}_{x}$ values, but fixed standard deviations $\sigma_{x}$. Collision kernels are taken from Fuchs (1964), using $\bar{r}_{x}$ as representative radius for the respective log-normal distribution.

The model considers self-coagulation of neutral and ion particles (paths $n \rightarrow n$ and $i \rightarrow i$; see closed arrows in Fig. 2) as well as scavenging losses of neutral and ion particles by soot, background and ice particles (paths $n, i \rightarrow s, n, i \rightarrow b$, $n, i \rightarrow i c e$; see arrows in Fig. 2). The arrow $n \rightarrow i$ indicates the key growth path of particles in mode $i$ at the expense of particles from mode $n$, which rapidly decays in the plume.
Loss of particles from mode $x=i, n$ due to self-coagulation $(y=x)$ and scavenging by larger particles $(y=s, b, i c e$ and $i$ if $x=n$ ) is:

$\frac{d n_{x}}{d t}=-\underbrace{0.5 K_{x x}^{\text {coag }} n_{x}^{2}}_{\text {selfcoagulation }}-\underbrace{K_{x y}^{\text {coag }} n_{x} n_{y}}_{\text {scavenging }}$,

where $K_{x y}^{\text {coag }}=2 \pi\left(\bar{r}_{x}+\bar{r}_{y}\right)\left(D_{x}+D_{y}\right) \beta$ represents the average Kernel for coagulation between modes $x$ and $y$, with diffusion constants $D$ for particles in air and a correction factor $\beta$ accounting for the gas kinetic effects occurring within about a mean free paths' distance away from the particle surface (Fuchs, 1964). As $K^{\text {coag }}$ is a function of particle size, the coagulation efficiency increases not only with particle number densities, but also with increasing particle size of mode $y\left(r_{y}\right)$. However, for simplification equal composition is assumed throughout an entire particle mode.

Self-coagulation increases the mode radius of the respective mode, but does practically not change the composition, nor the total mass of the particle mode. Scavenging of particles from mode $x$ by mode $y$, on the other hand, leaves $n_{y}$ unchanged, whereas the mode radius of mode $y$ increases due to mass transfer from mode $x$ according to $d\left(n_{y} m_{y}\right) / d t=K_{x y}^{\text {coag }} n_{y} n_{x} m_{x}$, where $m$ denotes the average mass of a particle of the respective mode. Note that the mass transfer from $x$ to $y$ does not only change $\bar{r}_{y}$, but also modifies the average composition of mode $y$. This has to be taken into account, as it might cause changes in solubility of heterogeneously reacting species.

\subsubsection{Gas diffusive condensation/evaporation}

Besides mass transfer from one mode to another due to coagulation, the different particle modes interact via the gas phase by gas diffusive condensation and evaporation of $\mathrm{H}_{2} \mathrm{O}$ and $\mathrm{HNO}_{3}$ :

$$
\frac{d}{d t} N_{j}=\frac{4 \pi r D_{j}^{\star}}{k_{B} T}(p_{j}^{\infty}-\underbrace{p_{j, \text { vlat }}^{\text {vap }} K_{j}(r)}_{p_{j}^{\text {vap }}(r)})
$$

This equation describes the change of molecules $N_{j}$ of a species $j$ contained in a particle of radius $r$. $D_{j}^{\star}$ is the effective gas diffusion constant (Pruppacher and Klett, 1997), $k_{B}$ is the Boltzmann constant, $T$ is the atmospheric temperature, $p_{j}^{\infty}$ is the partial pressure far away from the droplet and $p_{j, \text { flat }}^{\text {vap }}$ is the vapor pressure of $i$ over a planar bulk solution depending on temperature and particle composition (Luo et al., 1995). The change of vapor pressure due to the surface curvature is given by the Kelvin term $K_{j}$, which becomes important for small particles $(r \leq 0.05 \mu \mathrm{m}$,).

Background aerosols entrained from the unperturbed background atmosphere may encounter completely different water and $\mathrm{HNO}_{3}$ concentrations in the plume. Depending on relative humidity, entrained liquid background 

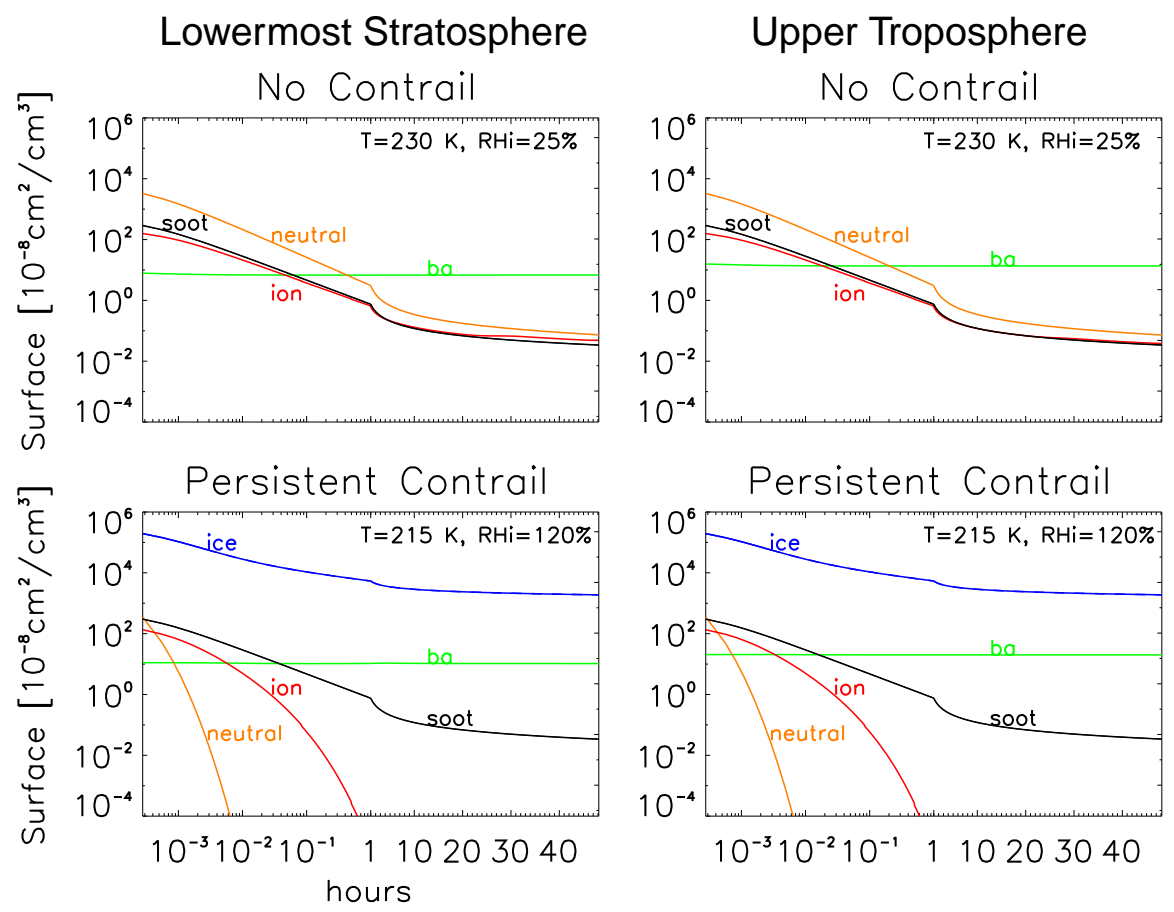

Fig. 3. Surface area of aviation produced particles and entrained background aerosols as a function of time. Assumed emission indices are given in Table 1. Initial conditions of the background atmosphere are the same as in Meilinger et al. (2001), assuming 25 (100) ppmv $\mathrm{H}_{2} \mathrm{O}$ and 0.87 (0.17) ppbv $\mathrm{HNO}_{3}$, and 100 (200) pptv $\mathrm{H}_{2} \mathrm{SO}_{4}$ in background aerosol particles with number density $500 \mathrm{~cm}^{-3}\left(1000 \mathrm{~cm}^{-3}\right)$ above (below) the local tropopause (see left (right) panel)). Different temperatures (as indicated) are considered, (not) allowing for persistent contrail formation (see upper (lower) panels) with temperatures and relative humidities as indicated. Note that abscissa is logarithmic at $t<1 \mathrm{~h}$ and linear at $t>1 \mathrm{~h}$.

aerosols might grow or shrink when entrained into the plume. Growth and evaporation of the nanometer-sized volatile aircraft particles, on the other hand, are limited by the Kelvin effect. Therefore, the model considers gas diffusive condensation/evaporation for each mode separately, but coupled through interaction with the gas phase. Again, for simplification equal composition is assumed throughout an entire particle mode.

\section{Results}

In the following, results of the Mainz Aircraft Plume Model are shown, describing the microphysical and chemical evolution of a spreading plume (1 s-2 days). Calculations are shown for emissions in the NAFC $\left(50^{\circ} \mathrm{N}\right)$ in March at 9:00 $\mathrm{h}$ local time $\left(67^{\circ}\right.$ solar zenith angle) at $200 \mathrm{hPa}$. We consider emissions deposited into the upper troposphere as well as into the lowermost stratosphere, assuming different mixing ratios of longlived species in the background atmosphere (same as in Meilinger et al., 2001). Above (and in parentheses below) the tropopause we assume 275 (29) ppbv $\mathrm{O}_{3}, 44$ (57) ppbv CO, 0.87 (0.17) ppbv $\mathrm{HNO}_{3}, 75$ (204) pptv $\mathrm{H}_{2} \mathrm{O}_{2}$, 1.7 ppmv $\mathrm{CH}_{4}, 325$ (145) pptv $\mathrm{Cl}_{y}, 2.78$ (0.98) pptv $\mathrm{Br}_{y}$, 100 pptv (1 ppbv) $\mathrm{C}_{2} \mathrm{H}_{6}, 100$ pptv (600 pptv) acetone and
40 pptv (150 pptv) PAN. In addition we distinguish conditions with $\left(T=215 \mathrm{~K}, R H_{i}=120 \%\right)$ and without $(T=230 \mathrm{~K}$, $R H_{i}=25 \%$ ) contrail formation.

\subsection{Surface area and heterogeneous chemistry}

The surface area of aircraft-induced liquid particles is initially 2-3 orders of magnitude above that of the liquid background aerosol (Fig. 3). This perturbation disappears gradually due to plume dilution and coagulation. While in the noncontrail case (upper panels in Fig. 3) the surface perturbation due to the presence of liquid exhaust particles needs about $1 \mathrm{~h}$ to reduce to the order of the entrained background aerosols, it disappears within minutes in the case of contrail formation (lower panels in Fig. 3). This is due to enhanced scavenging by the larger ice particles. Even if contrails do not persist (not shown) initial scavenging by ice particles efficiently reduces the aircraft induced volatile particles. The ice particles themselves increase the reactive surface area by initially about 4 orders of magnitude compared to the background aerosol. In persistent contrails the ice particle number densities steadily decrease due to plume dilution. After about 2 days, which corresponds to the mean plume encounter time, $t_{l}$, of an aged plume by another aircraft in the NAFC (Kärcher and Meilinger, 1998), the surface area enhancement caused 
Lowermost Stratosphere
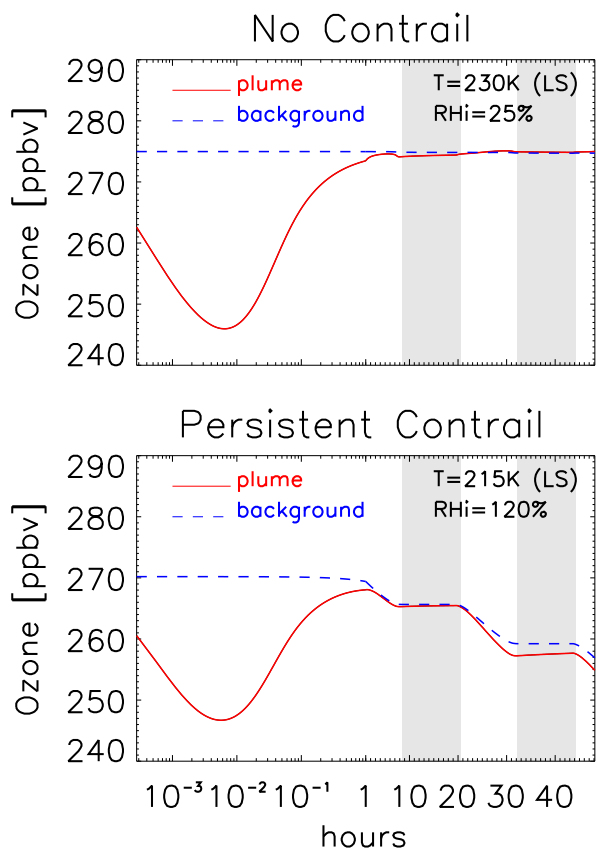

Upper Troposphere

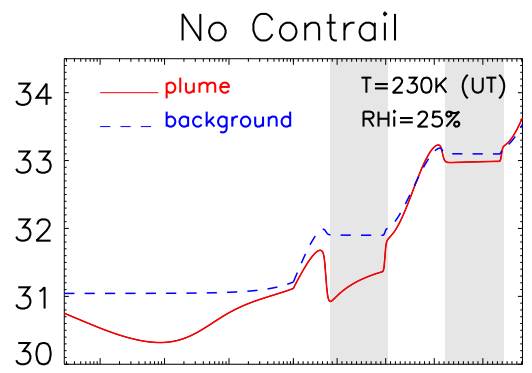

Persistent Contrail

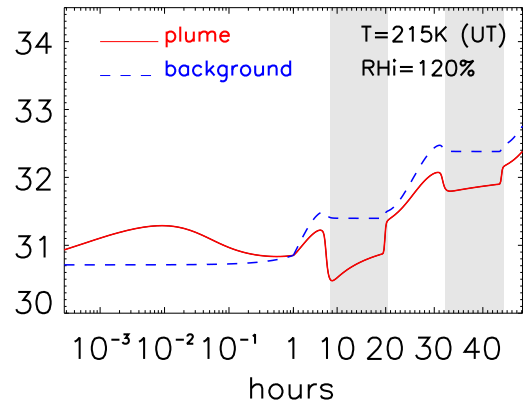

Fig. 4. Ozone concentrations along the plume axis, shown as a function of plume age for emissions into the lowermost stratosphere (left) and upper troposphere (right) considering cases of contrail (lower panels) and of non-contrail (upper panels) formation. Same conditions as in Fig. 3. The white and shaded areas indicate day and night.

by contrail ice (assuming the contrail persists this long) particles still exceeds the background aerosol surface area by about 2-3 orders of magnitude (lower panels in Fig. 3).

A detailed analysis of heterogenous processes on aircraft induced particles reveals, that in the non-contrail case heterogeneous hydrolysis of $\mathrm{BrONO}_{2}$ and $\mathrm{N}_{2} \mathrm{O}_{5}$ dominates leading to bromine activation and an increased conversion of aircraft emitted $\mathrm{NO}_{\mathrm{x}}$ into $\mathrm{HNO}_{3}$. In contrails heterogenous chemistry on ice particles becomes very efficient, clearly influencing plume chemistry (see below). In the lowermost stratosphere chlorine activation on contrail ice particles is the most important heterogeneous process, while in the upper troposphere the heterogeneous selfreaction of $\mathrm{HO}_{\mathrm{x}}$ dominates. This different chemical behavior of contrails below and above the tropopause is similar to the influence of cirrus clouds as described by Meilinger et al. (2001).

\subsection{Plume chemistry and impact on ozone}

In all considered cases, early plume chemistry (first minutes) is dominated by the ozone titration reaction $\mathrm{NO}+\mathrm{O}_{3}$, which is partly compensated by $\mathrm{NO}_{2}$ photolysis. As $\mathrm{NO}_{\mathrm{x}}$ is converted into its reservoir species (next subsection) and mixing with ambient air becomes more important, ozone chemistry in the aging plume depends on whether emissions are deposited into the upper troposphere or lowermost stratosphere and whether or not a contrail formed.
Lowermost stratosphere: Due to the high abundance of $\mathrm{O}_{3}$ in the lowermost stratosphere $\mathrm{NO}+\mathrm{O}_{3}$ dominates in the early plume leading to short-term ozone depletion (left panel of Fig. 4). While $\mathrm{NO}+\mathrm{O}_{3}$ leads to efficient ozone destruction during the first minutes, entrainment of ozone rich air and ozone production via photolysis of $\mathrm{NO}_{2}$ lead to increasing ozone mixing ratios already within the first hour. Without contrail formation (upper left panel of Fig. 4) heterogeneously activated bromine $\left(\mathrm{Br}+\mathrm{O}_{3}\right)$ slightly enhances ozone depletion during the first minutes. In addition ozone is depleted during night via $\mathrm{NO}_{2}+\mathrm{O}_{3}$. However these processes cannot overcome the $\mathrm{NO}_{\mathrm{x}}$ induced ozone production (via $\mathrm{NO}+\mathrm{HO}_{2}$ and photolysis of $\mathrm{NO}_{2}$ ) in the aged plume (after $20 \mathrm{~h}$ ). In the case of contrail formation, however, the ozone destruction due to heterogeneously activated chlorine $\left(\mathrm{Cl}+\mathrm{O}_{3}\right)$ and bromine $\left(\mathrm{Br}+\mathrm{O}_{3}\right)$ not only efficiently enhances the NO induced ozone depletion in the early plume, but even dominates $\mathrm{NO}_{\mathrm{x}}$-induced ozone production in the aged plume (lower left panel of Fig. 4). This is due to heterogeneous chemistry on contrail ice particles leading to very efficient halogen activation on the one hand and heterogeneous denoxification on the other hand. In addition dehydration of the supersaturated ambient air due to contrail formation and heterogeneous dehoxification lead to a lower abundance of $\mathrm{HO}_{2}$, which efficiently reduces the ozone production via $\mathrm{NO}+\mathrm{HO}_{2}$ and - as a consequence - of $\mathrm{NO}_{2}$ photolysis (due to the lower abundance of $\mathrm{NO}_{2}$ ). This leads to an overall 

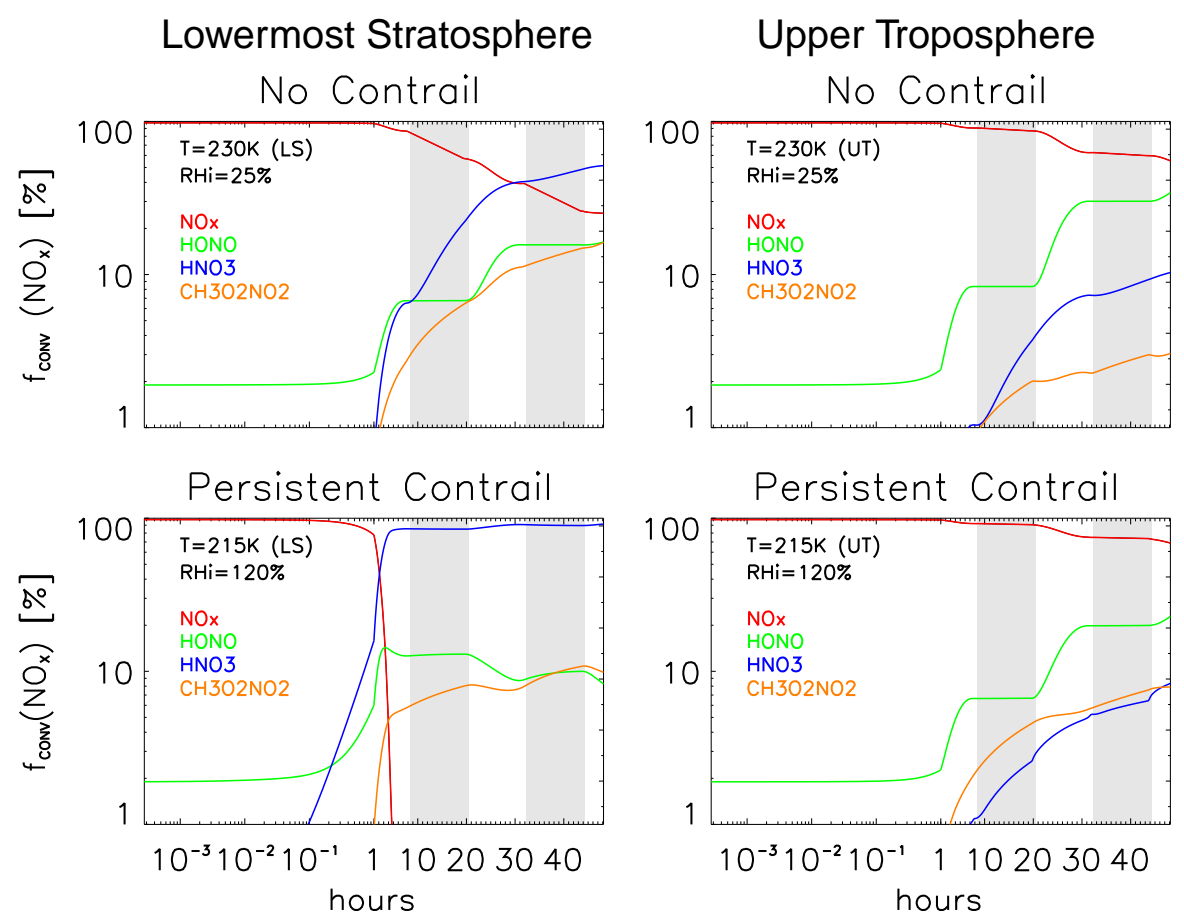

Fig. 5. Same as Fig. 4 but for chemical conversion factor $f_{c o n v}$ of emitted $\mathrm{NO}_{\mathrm{x}}$ into the main $\mathrm{NO}_{\mathrm{x}}$ reservoirs as indicated.

ozone depleting effect of contrails in the supersaturated lowermost stratosphere.

Upper troposphere: In the upper troposphere the overall effect of early plume chemistry is determined by the temperature dependence of catalytic ozone destruction. At higher temperatures NO induced ozone depletion is larger than ozone production via photolysis of $\mathrm{NO}_{2}$ (upper right panel of Fig. 4) while at low temperatures the ozone production dominates (lower right panel of Fig. 4). In the case without contrail formation (upper right panel of Fig. 4) $\mathrm{NO}_{\mathrm{x}}-$ induced ozone production dominates during daytime. Similar to plume chemistry in the lowermost stratosphere night time ozone depletion via $\mathrm{NO}_{2}+\mathrm{O}_{3}$ is enhanced due to the aircraft induced $\mathrm{NO}_{2}$ leading to the sharp decrease in ozone during night. However, on a longer timescale (of about 2 days) this cannot compensate the $\mathrm{NO}_{\mathrm{x}}$-induced ozone production. In the contrail case (lower right panel of Fig. 4), however, the ozone producing effect of $\mathrm{NO}_{\mathrm{x}}$-emissions is overcompensated by dehoxification due to dehydration of the supersaturated atmosphere and heterogeneous loss of $\mathrm{HO}_{2}$ on contrail ice particles.

\subsection{Conversion of $\mathrm{NO}_{\mathrm{x}}$ to reservoir species}

Figure 5 shows the chemical conversion $f_{\text {conv }}$ of emitted $\mathrm{NO}_{\mathrm{x}}$ to its reservoir species (similar to Kraabøl et al., 2000b) as a function of time, $f_{\text {conv }}\left(\mathrm{NO}_{\mathrm{x}}, t\right)=\Delta \mathrm{NO}_{\mathrm{x}}(t) / \Delta \mathrm{NO}_{\mathrm{y}}(t)$ where $\Delta \mathrm{NO}_{\mathrm{x}}(t)$ and $\Delta \mathrm{NO}_{\mathrm{y}}(t)$ denote the difference of $\mathrm{NO}_{\mathrm{x}}$ and $\mathrm{NO}_{\mathrm{y}}$ mixing ratios between plume and background at- mosphere at time $t$. In all cases, $\mathrm{HONO}$ and $\mathrm{HNO}_{3}$ are the most important reservoir species. While under upper tropospheric conditions, $\mathrm{NO}_{\mathrm{x}}$ is mainly converted into HONO (20-30\%), which remains the most important reservoir throughout the entire plume life-time, $\mathrm{HNO}_{3}$ becomes the main reservoir species under lowermost stratospheric conditions containing $50-90 \%$ of the emitted $\mathrm{NO}_{\mathrm{x}}$. This reveals the high sensitivity for $\mathrm{NO}_{\mathrm{x}}$ conversion on the exact conditions under which emissions take place (see also next section).

Upper troposphere: In the upper troposphere HONO production via $\mathrm{NO}+\mathrm{OH}+\mathrm{M}$ is the most important daytime conversion process throughout the entire plume lifetime. This is due to the fact, that $\mathrm{NO}_{\mathrm{x}}$ is mainly emitted in the form of $\mathrm{NO}$ and - as a consequence $-\mathrm{OH}$ is the main $\mathrm{HO}_{\mathrm{x}}$ species in the early plume. $\left(\mathrm{HO}_{2}\right.$ is converted to $\mathrm{OH}$ via $\mathrm{NO}+\mathrm{HO}_{2}$ ). Compared to the lowermost stratosphere heterogeneous production of $\mathrm{HNO}_{3}$ plays a minor role and the main upper tropospheric production mechanism of $\mathrm{HNO}_{3}$ is via $\mathrm{NO}_{2}+\mathrm{OH}+\mathrm{M}$. Therefore both, $\mathrm{HNO}_{3}$ and $\mathrm{HONO}$ production are reduced in the case of contrail formation, where dehoxification due to dehydration and heterogeneous $\mathrm{HO}_{\mathrm{x}}$ depletion leads to a lower abundance of $\mathrm{OH}$. Thus $\mathrm{NO}_{\mathrm{x}}$ conversion into $\mathrm{CH}_{3} \mathrm{O}_{2} \mathrm{NO}_{2}$ becomes more important.

Lowermost stratosphere: Similar to the upper troposphere HONO production via $\mathrm{NO}+\mathrm{OH}+\mathrm{M}$ is the most important conversion process during the first minutes after emission (for day time emissions). In the non-contrail case, 
$\mathrm{HNO}_{3}$ is readily produced via $\mathrm{NO}_{2}+\mathrm{OH}+\mathrm{M}$ and hydrolysis of bromine nitrate and $\mathrm{N}_{2} \mathrm{O}_{5}$. Due to the larger abundance of $\mathrm{NO}_{2}$ and of halogens in the lowermost stratosphere these heterogeneous reactions dominate compared to the upper troposphere. In the case of contrail formation, heterogeneous $\mathrm{NO}_{\mathrm{x}}$ to $\mathrm{HNO}_{3}$ conversion via hydrolysis of chlorine nitrate becomes the most important process, converting up to $90 \%$ of the emitted $\mathrm{NO}_{\mathrm{x}}$. At the same time heterogeneous $\mathrm{HO}_{\mathrm{x}}$ depletion reduces the $\mathrm{HONO}$ production via $\mathrm{NO}+\mathrm{OH}+\mathrm{M}$.

In all considered cases, the conversion to PAN was small due to a limited availability of the $\mathrm{CH}_{3} \mathrm{COO}_{2}$. As $\mathrm{N}_{2} \mathrm{O}_{5}$ is easily dissociated by UV-radiation it is not a reservoir for $\mathrm{NO}_{\mathrm{x}}$ during daytime and only builds up during night. Therefore heterogeneous conversion of $\mathrm{NO}_{\mathrm{x}}$ to $\mathrm{HNO}_{3}$ via hydrolysis of $\mathrm{N}_{2} \mathrm{O}_{5}$ only plays a role at time scales that allow for nighttime processes. Due to the relatively low abundance of halogen species in the tropopause region, chlorine- and bromine nitrate are of minor importance as $\mathrm{NO}_{\mathrm{x}}$-reservoir. However hydrolysis of these nitrates is an important pathway for the formation of $\mathrm{HNO}_{3}$ especially under lowermost stratospheric conditions.

\section{Effective emission and perturbation indices}

\subsection{Effective Emission Index (E EI)}

In order for global models to consider subgrid processes such as transformation of the pollutants during plume dispersion, the plume model results are translated into Effective Emission Indices $(E E I)$ of emitted species such as $\mathrm{NO}_{\mathrm{x}}$ (e.g. Petry et al., 1998), where $E E I$ is the product of conversion factor $f_{\text {conv }}$ (describing the chemical conversion of emissions in the dispersing plume) and the known Emission Index $(E I)$ which quantifies the in-engine process results (note that our conversion factor corresponds to the Plume Transformation Index, PTI, of Karol et al., 2000)

$$
E E I=f_{\text {conv }}\left(t_{l}\right) * E I,
$$

where $t_{l}$ is the average plume encounter time according to Kärcher and Meilinger (1998), which accounts for grid box size and for airtraffic density in the considered large-scalemodel area (see Fig. 6).

As grid sizes differ depending on model resolution and air traffic density, the respective $t_{l}$ differs as well and thus the corresponding $E E I \mathrm{~s}$ have to be respectively adjusted. Choosing the NAFC as grid box $\left(t_{l} \sim 46 \mathrm{~h}\right)$, Fig. 7 shows $E E I\left(\mathrm{NO}_{\mathrm{y}}\right)$ as a function of relative humidity with respect to ice $\left(R H_{i c e}\right)$ assuming an average tropopause temperature of $T=220 \mathrm{~K}$. Again we consider the two base cases (see last section) for emissions deposited into the upper troposphere (right panel) and lowermost stratosphere (left panel). In addition we distinguish various times of emissions and seasons as indicated.

\section{CONCEPT of PLUME LIFETIME}
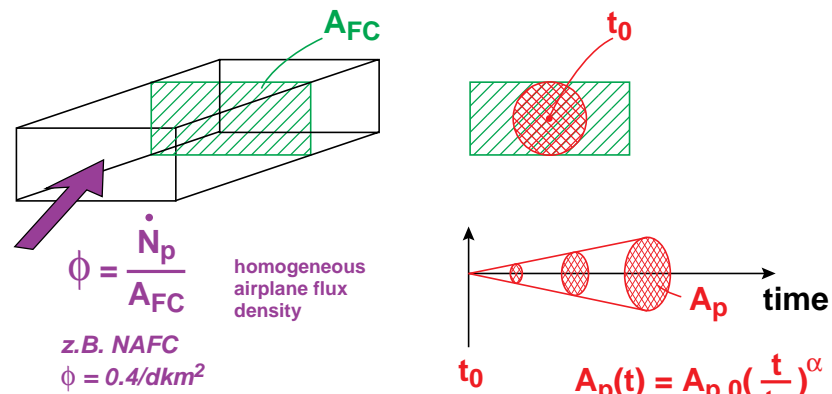

$\phi=0.4 / \mathrm{dkm}^{2}$

$t_{0}$

$$
\begin{aligned}
& A_{\mathrm{p}}(t)=A_{\mathrm{p}, 0}\left(\frac{\mathrm{t}}{\mathrm{t}_{0}}\right)^{\alpha} \\
& t_{0}=10 \mathrm{sec}
\end{aligned}
$$

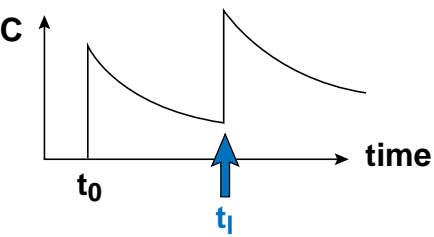

$A_{p, 0}=8.8 \cdot 10^{-4} \mathrm{~km}^{2}$

$\alpha=0.8$

$$
\begin{gathered}
N_{P}\left(t_{l}\right) \equiv 1=\int_{t_{0}}^{t_{I}} \phi A_{p}(t) d t \Rightarrow t_{I} \begin{array}{l}
\text { plume } \\
\text { encounter time }
\end{array} \\
t_{I}=t_{0}\left(1+\frac{1+\alpha}{\phi A_{p, 0} t_{0}}\right)^{1 / 1+\alpha}
\end{gathered}
$$

Fig. 6. Schematic description of average plume encounter time, $t_{l}$ of a single aircraft in a flight corridor. Assuming a homogeneous distribution of airplanes in a given volume (flight corridor or grid box), the average flux density of aircraft, $\Phi$, can be described by $\Phi=\dot{N}_{p} / A_{F C}$, where $\dot{N}_{p}$ is the average number of planes flying through the volume per unit time and $A_{F C}$ is the respective cross section. The plume cross section $A_{p}$ grows according to $A_{p}(t)=A_{p, 0}\left(t / t_{0}\right)^{\alpha}$, where $A_{p, 0}$ is the cross section at time $t_{0}$ and $\alpha$ parameterizes the mixing process. Thus the number of planes crossing an individual plume within a timespan $\left(t-t_{0}\right)$ is given by $N_{p}(t)=\int_{t_{0}}^{t} \Phi A_{p}(\tau) d \tau$. The average plume encounter time then simply follows from $N_{p}\left(t_{l}\right)=1$ (for the NACF $t_{l} \sim 46 \mathrm{~h}$ ). The concentration $c$ of an emitted species decreases during plume dilution until it is superposed by the emissions of the subsequent plane at time $t_{l}$.

Upper troposphere: In the upper troposphere (left panel) the $\mathrm{NO}_{\mathrm{x}}$ conversion rather depends on time of emission than on $R H_{\text {ice }}$. While conversion into $\mathrm{HNO}_{3}$ acounts for less than $10 \%$ up to $50 \%$ are converted into HONO. The high $\mathrm{NO}_{\mathrm{x}}$ to $\mathrm{HONO}$ conversion of $50 \%$ in summer is due to the large $\mathrm{HO}_{\mathrm{x}}$ levels compared to winter, where only $E E I(\mathrm{HONO}) \approx 15 \%$. If emissions encounter a supersaturated atmosphere $\left(R H_{i c e}>100 \%\right)$ dehydration due to contrail formation and heterogeneous dehoxification lead to a lower abundance of $\mathrm{HO}_{\mathrm{x}}$, reducing the $\mathrm{NO}_{\mathrm{x}}$ to $\mathrm{HONO}$ conversion.

Lowermost stratosphere: In the lowermost stratosphere (right panel) the conversion depends strongly on $R H_{i c e}$. While without contrail formation $\left(\mathrm{RH}_{\text {ice }}<60 \%\right)$ more than half of the emitted $\mathrm{NO}_{\mathrm{x}}$ is converted into $\mathrm{HONO}$ and $\mathrm{HNO}_{3}$, 


\section{Lowermost Stratosphere}

\section{Upper Troposphere}
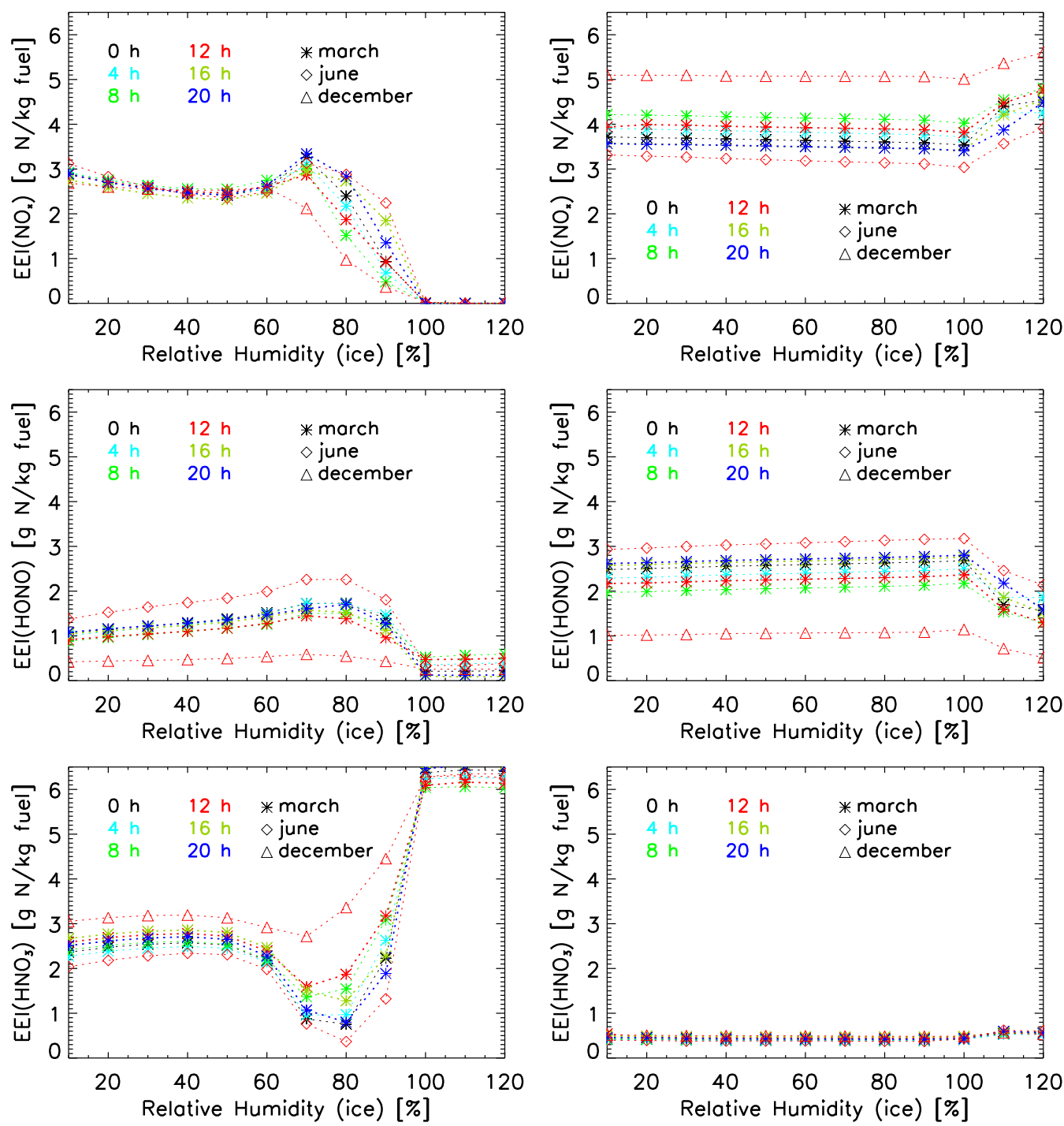

Fig. 7. Effective emission indices for the $\mathrm{NAFC}\left(t_{l} \sim 46 \mathrm{~h}\right)$ as a function of $R H_{i c e}$. Upper panel: $E E I\left(\mathrm{NO}_{\mathrm{x}}\right)$; middle panel: $E E I(\mathrm{HONO})$; lower panel: $E E I\left(\mathrm{HNO}_{3}\right)$. The initial emission index of nitrogen was $E I(\mathrm{~N})=6.5 \mathrm{~g} / \mathrm{kg}$ fuel. The different colors and symbols show results for different local times and seasons of emission as indicated. Left: emissions into the lowermost stratosphere; right: emissions into the upper troposphere (assuming the same background concentrations as for single plume calculations, see Sect. 3).

this conversion is reduced in the case of non-persistent contrail formation $\left(R H_{i c e}=70-90 \%\right)$. As $\mathrm{HO}_{\mathrm{x}}$ is more abundant for higher atmospheric water contents, HONO production slightly increases with relative humidity (especially for summer), while heterogeneous conversion of halogen nitrates into other halogen reservoirs during the contrail period (some seconds) limits heterogeneous production of $\mathrm{HNO}_{3}$. Due to the different dependence on sunlight $\mathrm{HNO}_{3}$ is the more important conversion product in winter while HONO production is larger in summer. In the case of persistent con- trail formation $\left(R H_{i c e} \leq 100 \%\right)$, however, these seasonal differences vanish and heterogeneous chemistry allows for an almost complete conversion of the emitted $\mathrm{NO}_{\mathrm{x}}$ into $\mathrm{HNO}_{3}$.

\subsection{Effective Perturbation Index $(E P I)$}

To describe the plume effect for atmospheric trace gases that are not emitted but undergo aircraft induced chemical processing within the dispersing plume, such as e.g. ozone, we define an effective perturbation index $(E P I)$, as the percent 


\section{Lowermost Stratosphere}

\section{Upper Troposphere}
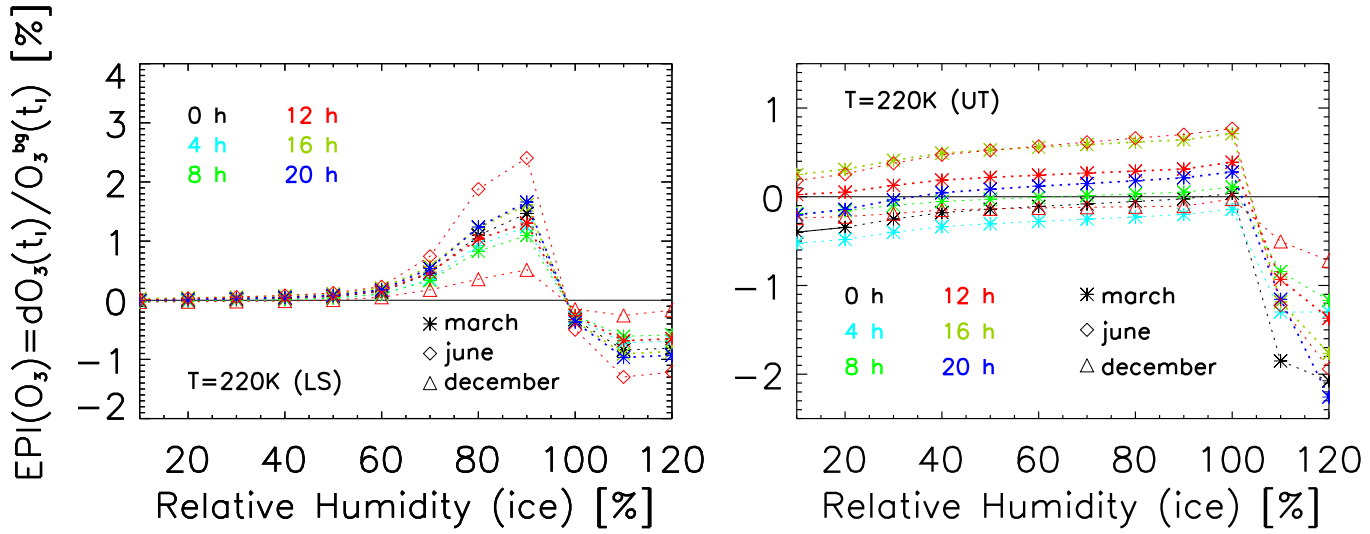

Fig. 8. Effective perturbation index of ozone for the NAFC as a function of $R H_{i c e}$. Times (marked by different colors) indicate local times of emission. Same conditions as in Fig. 7.

change of a trace species compared to the unperturbed background atmosphere at average plume encounter time, $t_{l}$ :

$E P I=\frac{\chi\left(t_{l}\right)-\chi_{b}\left(t_{l}\right)}{\chi_{b}\left(t_{l}\right)}$

Figure 8 shows $\operatorname{EPI}\left(\mathrm{O}_{3}\right)$ for the NAFC as a function of relative humidity for various times of emissions again distinguishing emissions deposited into the upper troposphere and lowermost stratosphere.

Without contrail formation $\left(R H_{i c e} \leq 60 \%\right.$ ), there is no significant effect on ozone within the average plume encounter time $\left(E P I\left(\mathrm{O}_{3}\right) \sim 0\right)$ if emissions are released into the lowermost stratosphere (left panel). The effect on upper tropospheric ozone depends strongly on time and season $\left(\operatorname{EPI}\left(\mathrm{O}_{3}\right) \sim \pm 0.5 \%\right)$. As humidity grows, $\operatorname{EPI}\left(\mathrm{O}_{3}\right)$ increases due to higher $\mathrm{NO}_{\mathrm{x}}$-assisted ozone production in photosmog reactions of hydrocarbons and carbon monoxide with $\mathrm{OH}$. In the upper troposphere however, this increase in EPI is only some promille, which is less than the difference of E P I for summer and winter emissions. In the lowermost stratosphere $E P I\left(\mathrm{O}_{3}\right)$ increases significantly for increasing relative humidity (up to $2 \%$ in summer). This is mainly due to the water dependence of $\mathrm{HO}_{\mathrm{x}}$, which is most abundant in summer, and due to higher $E E I\left(\mathrm{NO}_{\mathrm{x}}\right)$ which result from limited heterogeneous conversion to $\mathrm{HNO}_{3}$ due to repartitioning of the halogen reservoir species in the intermediate contrail. The negative values for $E P I\left(\mathrm{O}_{3}\right)$ in the contrail case are due to heterogeneous chemistry (heterogeneous $\mathrm{HO}_{\mathrm{x}}$ selfreaction in the upper troposphere and heterogeneous chlorine chemistry in the lowermost stratosphere) and dehoxification by dehydration via ice particle formation.

\section{Conclusions}

We show results of the Mainz Aircraft Plume Model, which calculates in-plume chemistry considering comprehensive microphysics and heterogeneous chemistry on aircraft induced and mixed-in background particles. In addition we use the concept of effective emission and perturbation indices to deduce $E E I\left(\mathrm{NO}_{\mathrm{y}}\right)$ and $\operatorname{EEP}\left(\mathrm{O}_{3}\right)$ for the NAFC.

Model results show high surface area perturbations in the case of persistent contrail formation, which decreases from initially 4 orders of magnitude to $\sim 2$ after about 2 days, whereas in the non-contrail case, the perturbations of initially 2-3 orders of magnitude gradually disappear due to plume dilution and coagulation. This indicates that heterogeneous chemistry becomes especially important in the case of persistent contrail formation.

Ozone concentrations along the plume axis are determined by the competition of ozone depletion via $\mathrm{NO}+\mathrm{O}_{3}$ titration and $\mathrm{NO}_{\mathrm{x}}$-assisted photochemical ozone production during the first minute. Then plume mixing with ambient air leads to a recovery of ozone. In aging plumes ( $1 \mathrm{~h}-2$ days) the effect of aircraft emissions on ozone depends on time and season of emission, on relative humidity with respect to ice and on the exact composition of the ambient atmosphere. In any of the considered cases however, contrail formation in a supersaturated environment effectively causes ozone destruction $\left(E P I\left(\mathrm{O}_{3}\right)<0\right)$. In the lowermost stratosphere this is due to heterogeneously activated chlorine, whereas in the upper troposphere ozone production is limited by heterogeneous dehoxification.

Similar to ozone, we find a high sensitivity for $\mathrm{NO}_{\mathrm{x}}$ conversion on the exact conditions under which emissions take place. While under upper tropospheric conditions $\mathrm{NO}_{\mathrm{x}}$ is mainly converted into $\mathrm{HONO}(15-45 \%), \mathrm{HNO}_{3}$ is the main reservoir species in the lowermost stratosphere (except for 
non-persistent contrails). In the upper troposphere $\mathrm{NO}_{\mathrm{x}}$ to $\mathrm{HONO}$ conversion is largest in summer when $\mathrm{HO}_{\mathrm{x}}$ is most abundant, while it is lowest for persistent contrail formation in winter, where dehydration and heterogeneous dehoxification limit the available $\mathrm{OH}$. Due to the higher abundance of halogens in the lowermost stratosphere $\mathrm{NO}_{\mathrm{x}}$ to $\mathrm{HNO}_{3}$ conversion via heterogeneous halogen chemistry becomes the most important conversion process, leading to an almost complete conversion in the case of persistent contrail formation.

While our understanding of heterogeneous halogen chemistry has grown substantially during the last decade, less detailed studies exist on heterogeneous chemistry of $\mathrm{HO}_{\mathrm{x}}$. The involved heterogeneous processes have been shown to be of key importance for atmospheric chemistry below the tropopause.

We have shown the high sensitivity of effective emissions and perturbations on the exact conditions under which emissions take place, in order to extrapolate calculations with the Mainz Aircraft Plume Model to a global scale. Therefore statistical information on the location of the various flight paths with respect to the tropopause is required for extrapolating results of the Mainz Aircraft Plume Model to a global scale. In addition, statistical information on the different emission times, leading to different solar zenith angles, is necessary. The heterogeneous effects of contrails are also highly sensitive to the contrail persistence time. This requires more detailed investigation considering temperature and humidity statistics for the flight corridor.

Acknowledgements. This work was supported by the Umweltbundesamt (Berlin, Germany) under contract 10402814.

Edited by: L. Carpenter

\section{References}

Applemann, H.: Derivation of jet-aircraft contrail-formation curves, Air Weather Service, Washington, AWS TR 105-145, 46, 1957.

Atkinson, R., Baulch, D. L., Cox, R. A., Hampson Jr., R. F., Kerr, J. A., Rossi, M. J., and Troe, J.: Summary of evaluated kinetic and photochemical data for atmospheric chemistry: Web Version January 1999, http://www.iupac-kinetic.ch.cam.ac. uk/index.html, 1-50, 1999.

Becker, G., Grooß, J.-U., McKenna, D. S., and Müller, R.: Stratospheric photolysis frequencies: Impact of an improved numerical solution of the radiative transfer equation, J. Atmos. Chem., 37, 217-229, 2000.

Brown, S. S., Miake-Lye, R. C., Anderson, M. A., Kolb, C. E., and Resch, T. J.: Aerosol dynamics in near-field aircraft plumes, J. Geophys. Res., 101, 22 939-22 954, 1996.

Carslaw, K. S., Peter, Th., and Clegg, S. L.: Modeling the composition of liquid stratospheric aerosols, Revs. Geophys., 35, 125154, 1997.

Curtis, A. R. and Sweetenham, W. P.: Facsimile/Chekmat User's Manual, Comp. Sci and Syst. Div. Harvell Lab., Oxford, UK, 1987.
Fahey, D. W., Keim, E. R., Boering, K. A., Brock, C. A., Wilson, J. C., Jonsson, H. H., Anthony, S., Hanisco, T. F., Wennberg, P. O., Miake-Lye, R. C., Salawitch, R. J., Louisnard, N., Woodbridge, E. L., Gao, R. S., Donnelly, S. G., Wamsley, R. D., DelNegro, L. A., Solomon, S., Daube, B. C., Wofsy, S. C., Webster, C. R., May, R. D., Kelly, K. K., Loewenstein, M., Podolske, J. R., and Chan, K. R.: Emission measurements of the Concorde supersonic aircraft in the lower stratosphere, Science, 270, 70-74, 1995.

Fuchs, N. A.: The mechanics of aerosols, Pergamon, 1964.

Gear, C. W.: The automatic integration of ordinary differential equations, Numer. Math., 14, 176-179, 1971.

Grooß, J.-U.: Modeling of stratospheric chemistry based on HALOE/UARS satellite data results, PhD thesis, Mainz, Shaker Verlag, ISBN 3-8265-1645-1, 133, 1996.

Hanson, D. R., Ravishankara, A. R., and Solomon, S.: Heterogeneous reactions in sulfuric acid aerosols: A framework for model calculations, J. Geophys. Res., 99, 3615-3629, 1994.

IPCC (Intergovernmental Panel on Climate Change): Aviation and the global atmosphere, edited by: Penner, J. E., Lister, D. H., Griggs, D. J., Dokken, D. J., and McFarland, M., Cambridge University Press, Cambridge, 1999.

Jacob, D. J.: Heterogeneous chemistry and tropospheric ozone, Atmos. Environ., 34, 2131-2159, 2000.

Jaeglé, L., Jacob, D. J., Brune, W. H., Faloona, I., Tan, D., Heikes, B. G., Kondo, Y., Sachse, G. W., Anderson, B., Gregory, G. L., Singh, H. B., Pueschel, R., Ferry, G., Blake, D. R., and Shetter, R. E.: Photochemistry of $\mathrm{HO}_{\mathrm{x}}$ in the upper troposphere at northern midlatitudes, J. Geophys. Res., 105, 3877-3892, 2000.

Kärcher, B., Hirschberg, M. M., and Fabian, P.: Small-scale chemical evolution of aircraft exhaust species at cruising altitude, J. Geophys. Res., 101, 15 169-15 190, 1996.

Kärcher, B.: Heterogeneous chemistry in aircraft wakes: Constraints for uptake coefficients, J. Geophys. Res., 102, 19119 $19135,1997$.

Kärcher, B., Busen, R., Petzold, A., Schröder, F., Schumann, U., and Jensen, E.: Physicochemistry of aircraft generated liquid aerosols, soot and ice particles - I. Model description, J. Geophys. Res., 103, 17 111-17 128, 1998a.

Kärcher, B., Busen, R., Petzold, A., Schröder, F., Schumann, U., and Jensen, E.: Physicochemistry of aircraft generated liquid aerosols, soot and ice particles - II. Comparison with observations and sensitivity studies, J. Geophys. Res., 103, 17129 17 147, 1998b.

Kärcher, B. and Meilinger, S. K.: Perturbation of the aerosol layer by aviation-produced aerosols: A parameterization of plume processes, Geophys. Res. Lett., 25, 4465-4468, 1998.

Kärcher, B.: Aviation-produced aerosols and contrails, Surv. Geophys., 20, 113-167, 1999.

Kärcher, B., Turco, R. P., Yu, F., Danilin, M. Y., Weisenstein, D. K., Miake-Lye, R. C., and Busen, R.: A Unified model for ultrafine aircraft particle emissions, J. Geophys. Res., 105, (D24), 29379 29386, 2000.

Karol, I. L., Ozolin, Y. E., and Kiselev, A. A.: Plume Transformation Index (PTI) of the Subsonic Aircraft Exhausts and their Dependence on the External Conditions, Geophys. Res. Lett., 27, 373-376, 2000.

Kraabøl, A. G., Flatøy, F., and Stordal, F.: Impact of $\mathrm{NO}_{\mathrm{x}}$ emissions from subsonic aircraft: Inclusion of plume processes in a 
three-dimensional model covering Europe, North America, and the North Atlantic, J. Geophys. Res., 105, 3573-3581, 2000a.

Kraabøl, A. G., Konopka, P., Stordal, F., and Schlager, H.: Modeling chemistry in aircraft plumes 1: comparison with observations and evaluation of a layered approach, Atmos. Environ., 34, 3939-3950, 2000b.

Kraabøl, A. G. and Stordal, F.: Modeling chemistry in aircraft plumes 2: the chemical conversion of $\mathrm{NO}_{\mathrm{x}}$ to reservoir species under different conditions, Atmos. Environ., 34, 3951-3962, 2000.

Lary, D. J. and Pyle, J. A.: Diffusive radiation, twilight and photochemistry, J. Atmos. Chem., 13, 373-406, 1991.

Luo, B. P., Carslaw, K. S., Peter, Th., and Clegg, S.: Vapor pressures of $\mathrm{H}_{2} \mathrm{SO}_{4} /-\mathrm{HNO}_{3} / \mathrm{HCl} / \mathrm{HBr} / \mathrm{H}_{2} \mathrm{O}$ solutions to low stratospheric temperatures, Geophys. Res. Lett., 22, 247-250, 1995.

Meijer, E. W., van Velthoven, P. F. J., Wauben, W. M. F., Beck, J. P., and Velders, G. J. M.: The effects of the conversion of nitrogen oxides in aircraft exhaust plumes in global models, Geophys. Res. Lett.24, 3013-3016, 1997.

Meilinger, S. K.: Heterogeneous Chemistry in the Tropopause Region - Impact of Aircraft Emissions, PhD thesis, Zürich, Diss. ETH No.13819, 113, 2000.

Meilinger, S. K., Kärcher, B., v. Kuhlmann, R., and Peter, Th.: On the Impact of Heterogeneous Chemistry on Ozone in the Tropopause Region, Geophys. Res. Lett., 28, 515-518, 2001.

Meilinger, S. K., Kärcher, B., and Peter, Th.: Suppression of chlorine activation on aviation-produced volatile particles, Atmos. Chem. Phys., 2, 307-312, 2002,

SRef-ID: 1680-7324/acp/2002-2-307.

Peter, Th.: Microphysics and heterogeneous chemistry of polar stratospheric clouds, Annu. Rev. Phys. Chem., 48, 785-822, 1997.
Petry, H., Hendricks, J., Möllhoff, M., Lippert, E., Meier, A., and Ebel, A.: Chemical conversion of subsonic aircraft emissions in the dispersing plume: Calculation of effective emission indices, J. Geophys. Res., 103, 5759-5772, 1998.

Petzold, A., Stein, C., Nyeki, S., Gysel, M., Weingartner, E., Baltensperger, U., Giebl, H., Hitzenberger, R., Düpelheuer, A., Vrchoticky, S., Puxbaum, H., Johnson, M., Hurley, C. D., Marsh, R., and Wilson, C. W.: Properties of jet engine combustion particles during the PartEmis experiment: Microphysics and chemistry. Geophys. Res. Lett., 30, doi:10.1029/2003GL017283, 2003.

Pruppacher, H. R. and Klett, J. D.: Microphysics of Clouds and Precipitation, Kluwer Academic Publishers, Dordrecht, 1997.

Sander, S. P., Friedl, R. R., Golden, D. M., Kurylo, M. J., Huie, R. E., Orkin, V. L., Moortgat, G. K., Ravishankara, A. R., Kolb, E. C., Molina, M. J., and Finlayson-Pitts, B. J.: Chemical kinetics and photochemical data for use in atmospheric studies, Evaluation Number 14, JPL Publication 02-25, Pasadena, 2003.

Schröder, F., Kärcher, B., Petzold, A., Baumann, R., Busen, R., Hoell, C., and Schuhmann U.: Ultrafine aerosol particles in aircraft plumes: In situ observations, Geophys. Res. Lett., 25, 2789-2792, 1998.

Schröder, F., Kärcher, B., Duroure, C., Ström, J., Petzold, A., Gayet, J.-F., Strauss, B., and Wendling, P.: On the transition of contrails into cirrus clouds, J. Atmos. Sci., 57, 464-480, 2000.

Schumann, U.: On conditions for contrail formation form aircraft exhaust, Meteorol. Z. N. F., 5, 4-23, 1996.

Schumann, U., Schlager, H., Arnold, F., Baumann, R., Haschberger, P., and Klemm, O.: Dilution of aircraft exhaust plumes at cruise altitudes, Atmos. Environ., 32, 3097-3103, 1998. 